\title{
Symbionts and diseases of farmed mussels Mytilus galloprovincialis throughout the culture process in the Rías of Galicia (NW Spain)
}

\author{
Antonio Villalba, Susana G. Mourelle, María J. Carballal, Carmen López \\ Centro de Investigacións Mariñas, Consellería de Pesca, Marisqueo e Acuícultura, Xunta de Galicia, Aptdo. 13, \\ E-36620 Vilanova de Arousa, Spain
}

\begin{abstract}
Mediterranean mussels Mytilus galloprovincialis were experimentally cultured from 5 rafts located in 4 Galician Rías, following the established industrial procedure. Cultures were sampled monthly until mussels exceeded market size. Observation of histological sections of sampled mussels by light microscopy demonstrated symbionts which could be classified into 3 groups according to their pathogenicity. The first group consisted of symbionts with unnoticeable pathogenic effects including: prokaryotic inclusion bodies (PIB) in digestive gland and gills, an unidentified protistan in digestive primary ducts, a kidney coccidian, intracytoplasmic ciliates in digestive tubules, gill ciliates and a turbellarian in the intestinal lumen. The second group comprised symbionts that could damage the host, although unlikely to be lethal, including: the microsporidian Steinhausia mytilovum, the flatworm Usastoma cyprinae, and the copepod Mytilicola intestinalis. The third group included the protistan Marteilia refringens and the trematode Proctoeces maculatus, potentially lethal pathogens. In addition, mussels with haemocytic infiltration of tissues and granulocytomas and a few cases of disseminated neoplasia were detected. The qualitative composition of mussel symbiont community was similar at the 5 study sites, except for 3 symbionts which were not detected at some sites. Quantitatively, symbiont loads were higher and histological signs of stress more abundant in Moana and Vilagarcia (the most inner sites in the Rías), intermediate in Illa de Arousa and Muros, and lower in Lorbé. Symbionts increased in prevalence as mussels grew. Some of the symbionts were detected in mussel seed at the beginning of the experimental cultures.
\end{abstract}

KEY WORDS: Mytilus galloprovincialis Symbionts Parasites Prokaryota Protista - Metazoa Pathological conditions - Neoplasia

\section{INTRODUCTION}

The farming of mussels Mytilus galloprovincialis in the Rías of Galicia (NW Spain) constitutes a very important industry (Pérez-Camacho et al. 1991). Around 3500 rafts are used with an annual production of approximately $200000 \mathrm{t}$ of mussels (FAO 1992). This mass culture of mussels markedly impacts the ecosystem of the Rías (Tenore et al. 1982). Since the introduction of mussel raft culture in Galician Rías, in the late 1940 s, mortality rates have not been significant, despite the high density of mussels that could facilitate the spread of epizootic diseases. Nevertheless, diminished harvests and reduced mussel condition were claimed by farmers in the late 1980s. Prior to this, no comprehensive study on the pathological conditions affecting mussels in Galicia had been completed, although studies documented the occurrence of the copepod Mytilicola intestinalis (Andréu 1963, 1965, Figueras \& Figueras 1981, Paul 1983), larval stages of the trematode Proctoeces maculatus (Canzonier 1972, Gutiérrez 1978, Ferrer 1981), the protistan Marteilia refringens (Gutiérrez 1977) and a haemocytic sarcoma (Gutiérrez \& Sarasquete 1986).

During the late 1980s, increasing interest in mussel pathology produced several surveys: González et al. (1987) in the Ría de Arousa and Ría de Ares-Betanzos, Figueras et al. (1991a) in the Ría de Arousa, and Robledo et al. (1994c) in the Ría de Vigo. Those surveys were mostly focused on adult mussels. However cul- 
ture practices in the region involve collection of mussel seed from either intertidal beds or collecting ropes and their transplantation onto culture ropes (PérezCamacho et al. 1991). Therefore, the movement of mussel seed batches is widespread throughout the Rías of Galicia, and this could influence the distribution of mussel parasites.

A programme began in 1988 in order to determine the symbionts and pathological conditions affecting mussels at every culture stage throughout the different Rías where they are grown. Results of this programme concerning mussel mortality rates and infection with the protistan Marteilia refringens (the most serious pathogen detected thus far) were published earlier (Villalba et al, 1993b). Here, the symbionts and pathologicdl conditions, thelr prevalence through the culture stages, and their distribution in the Galician Rias are presented.

\section{MATERIALS AND METHODS}

Experimental cultures were established from rafts in 5 zones of mussel farming (Fig. 1), as previously described (Villalba et al. 1993b). Briefly, cultures were started between February and May 1988 at Illa de Arousa, Vilagarcía, Muros, and Lorbé by tying mussel seed (ca $2 \mathrm{~cm}$ long) on ropes hung from the rafts. After $6 \mathrm{mo}$, the culture ropes were thinned and mussels transferred onto new ropes. The culture at Moaña

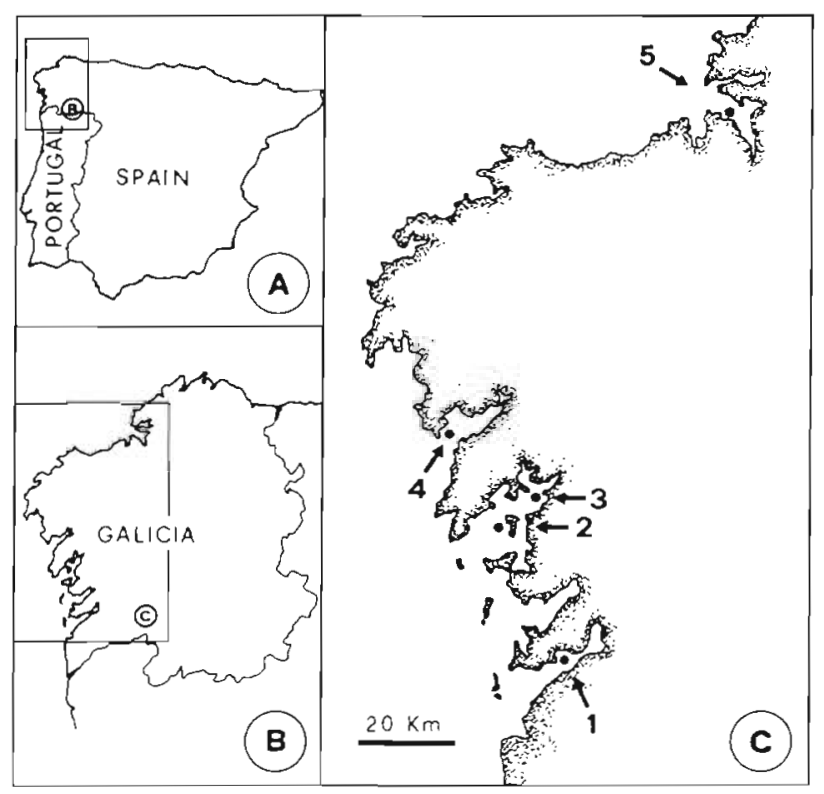

Fig. 1. Location of the experimental cultures in the Galician Rías. 1: Moaña (Ría de Vigo); 2: Illa de Arousa (Ría de Arousa); 3: Vilagarcía (Ría de Arousa); 4: Muros (Ría de Muros); 5: Lorbé (Ría de Ares-Betanzos) began with the thinning-out process, in September 1988. The cultures were terminated when market size ( $7 \mathrm{~cm}$ long) had been exceeded, in August and September 1989. Mussel seed was obtained from intertidal beds on rocky shores at different locations in Galicia: Illa de Toraia for the raft at Moaña, Santa María de Oia for the rafts at Illa de Arousa and Vilagarcia, Muros for the raft at Muros, and O Pindo for the raft at Lorbé.

Samples of 30 mussels were taken monthly from each experimental site. An approximately $5 \mathrm{~mm}$ thick section of tissue, containing gill, visceral mass, foot, and mantle lobes, was excised from every sampled specimen, fixed in Davidson's solution and embedded in paraffin. Sections of $6 \mu \mathrm{m}$ thickness were stained with Harris' hematoxylin and eosin (H\&E) (Howard \& Smith 1983) and Gomori's trichrome (GTC) (Luna 1968). Histological sections were examined with light microscopy for the presence of symbionts, pathological conditions, and signs of stress, including haemocytic infiltration of tissues and occurrence of granulocytomas (Bayne et al. 1985). The percentage of mussels affected by each symbiont and pathological condition was determined for each monthly sample. A monthly prevalence mean was calculated for each symbiont and pathological condition by averaging the monthly prevalence records pooled from all sites, in order to determine temporal patterns during culture.

Sites were compared by calculating the average prevalence of each symbiont and pathological condition for the whole study period in each site. Then sites were ranked for each symbiont and pathological condition by scoring sites from 1 (highest average prevalence) to 5 (lowest average prevalence); the mean rank was calculated for each site. Mean ranks were compared by the Kruskal-Wallis test followed by nonparametric multiple comparisons (simultaneous test procedure) (Sokal \& Rohlf 1981).

\section{RESULTS}

Prokaryotic inclusion bodies (PIB), similar to Rickettsia-like colonies reported from different bivalve species, were found in cells of the digestive gland and gills. In digestive gland epithelia, they were mostly located in digestive tubules, less frequently in secondary ducts, and rarely in primary ducts. They appeared in sections as oval shaped, intracytoplasmic inclusions, 7 to $20 \mu \mathrm{m}$ in diameter, close to the distal border of the host cell with different degrees of basophilia and granulated texture (Fig. 2). Very few PIB per histological section were found in the infected mussels and a concurrent haemocytic reaction was not observed. PIB were detected throughout the study 
period without temporal variation (see Fig. 18). The average prevalence was low at every site (Table 1). In the gills, PIB were elongated, 10 to $25 \mu \mathrm{m}$ long, and located in endothelial cells surrounding the branchial vein of the filaments (Fig. 3). Very few of these PIB per section were found in infected mussels; there was no haemocytic reaction. PIB in gills were detected only in samples from the Illa de Arousa, Vilagarcía and Muros with very low prevalence (Table 1). Apart from hypertrophy of the infected host cells no other damage attributable to PIB in digestive gland and gills was detected.

Cells of an unidentified protistan (probably a coccidian) were detected in the lumina of primary digestive ducts, attached to the host epithelium. They appeared as spherical basophilic cells, 13 to $22 \mu \mathrm{m}$ in diameter with granular cytoplasm and some round clear areas (Fig. 4). Very few cells of this protistan were found per section and no haemocytic response was observed. This unidentified protistan was detected at every study site with very low prevalence (Table 1). The prevalence was somewhat higher in 1989 (see Fig. 18).

Two different stages of a Pseudoklossia-like coccidian occurred in the kidney. Subspherical gamonts $8 \mu \mathrm{m}$ long, each with a large nucleus and distinct nucleolus, were observed inside kidney cells. Most infected host celis protruded into the nephridial lumen, and they were attached to the renal epithelium by a delicate stalk (Fig. 5). In addition, a mature spherical oocyst (27 $\mu \mathrm{m}$ in diameter) enclosing numerous sporocysts (ca $3.5 \mu \mathrm{m}$ in diameter) was found attached to the renal epithelium (Fig. 6). No lesion other than the infected host cell hypertrophy was detected; there was no inflammatory reaction. Intensity was very low and only 2 infected mussels (Vilagarcía and Lorbé) were detected during the study (Table 1 ; see Fig. 18).

The different stages characterizing the life cycle of the paramyxean Marteilia refringens were found in the
Table 1. Occurrence of symbionts and diseases of farmed Mytilus galloprovincialis. a: Average prevalence of each symbiont or pathological condition for the whole study period at each site; b: highest monthly record of prevalence of each symbiont and pathological condition at each site; $c$ : number of monthly samples in which each symbiont and pathological condition was detected at each site. The mean rank, calculated after ranking sites for each symbiont and pathological condition, is shown at the bottom. Note that the lower the mean rank the higher the symbiont load. n: number of monthly samples examined from each site

\begin{tabular}{|c|c|c|c|c|c|c|}
\hline & & $\begin{array}{c}\text { Moaña } \\
\mathrm{n}=12\end{array}$ & $\begin{array}{c}\text { llla de A } \\
\mathrm{n}=17\end{array}$ & $\begin{array}{l}\text { Vilagarcia } \\
n=18\end{array}$ & $\begin{array}{l}\text { Muros } \\
n=17\end{array}$ & $\begin{array}{l}\text { Lorbé } \\
n=17\end{array}$ \\
\hline Digestive gland PIB & $\begin{array}{l}a \\
b \\
c\end{array}$ & $\begin{array}{c}4.4 \\
13.3 \\
6\end{array}$ & $\begin{array}{c}3.1 \\
20.0 \\
9\end{array}$ & $\begin{array}{l}4.1 \\
16.7 \\
14\end{array}$ & $\begin{array}{c}2.0 \\
10.0 \\
8\end{array}$ & $\begin{array}{l}1.4 \\
6.7 \\
6\end{array}$ \\
\hline Gill PIB & $\begin{array}{l}a \\
b \\
c\end{array}$ & $\begin{array}{l}0 \\
0 \\
0\end{array}$ & $\begin{array}{l}0.4 \\
6.7 \\
1\end{array}$ & $\begin{array}{l}0.2 \\
3.3 \\
1\end{array}$ & $\begin{array}{l}0.6 \\
3.3 \\
3\end{array}$ & $\begin{array}{l}0 \\
0 \\
0\end{array}$ \\
\hline Dig. gl. unident. protistan & $\begin{array}{l}\mathrm{a} \\
\mathrm{b} \\
\mathrm{c}\end{array}$ & $\begin{array}{l}1.1 \\
6.7 \\
3\end{array}$ & $\begin{array}{c}1.2 \\
10.0 \\
3\end{array}$ & $\begin{array}{l}0.2 \\
3.3 \\
1\end{array}$ & $\begin{array}{l}0.8 \\
6.7 \\
3\end{array}$ & $\begin{array}{c}1.8 \\
10.0 \\
6\end{array}$ \\
\hline Kidney coccidian & $\begin{array}{l}a \\
b \\
c\end{array}$ & $\begin{array}{l}0 \\
0 \\
0\end{array}$ & $\begin{array}{l}0 \\
0 \\
0\end{array}$ & $\begin{array}{l}0.2 \\
3.3 \\
1\end{array}$ & $\begin{array}{l}0 \\
0 \\
0\end{array}$ & $\begin{array}{l}0.2 \\
3.3 \\
1\end{array}$ \\
\hline Marteilia refringens & $\begin{array}{l}a \\
b \\
c\end{array}$ & $\begin{array}{l}16.9 \\
36.7 \\
12\end{array}$ & $\begin{array}{l}10.8 \\
23.3 \\
15\end{array}$ & $\begin{array}{l}30.0 \\
63.3 \\
16\end{array}$ & $\begin{array}{l}0 \\
0 \\
0\end{array}$ & $\begin{array}{c}2.6 \\
20.0 \\
6\end{array}$ \\
\hline Steinhausia mytilovum ${ }^{a}$ & $\begin{array}{l}a \\
b \\
c\end{array}$ & $\begin{array}{r}8.2 \\
28.3 \\
4\end{array}$ & $\begin{array}{c}1.3 \\
14.6 \\
2\end{array}$ & $\begin{array}{c}1.5 \\
13.1 \\
3\end{array}$ & $\begin{array}{c}2.3 \\
10.7 \\
6\end{array}$ & $\begin{array}{c}2.1 \\
13.1 \\
4\end{array}$ \\
\hline Digestive gland ciliates & $\begin{array}{l}a \\
b \\
c\end{array}$ & $\begin{array}{l}31.9 \\
90.0 \\
10\end{array}$ & $\begin{array}{l}13.9 \\
43.3 \\
13\end{array}$ & $\begin{array}{l}14.7 \\
76.7 \\
15\end{array}$ & $\begin{array}{l}11.8 \\
33.3 \\
15\end{array}$ & $\begin{array}{l}26.9 \\
90.0 \\
14\end{array}$ \\
\hline Gill ciliates & $\begin{array}{l}a \\
b \\
c\end{array}$ & $\begin{array}{l}23.6 \\
66.7 \\
10\end{array}$ & $\begin{array}{l}29.0 \\
93.3 \\
15\end{array}$ & $\begin{array}{l}37.4 \\
93.3 \\
16\end{array}$ & $\begin{array}{l}39.6 \\
90.0 \\
13\end{array}$ & $\begin{array}{l}27.8 \\
83.3 \\
15\end{array}$ \\
\hline Intestine turbellarian & $\begin{array}{l}a \\
b \\
c\end{array}$ & $\begin{array}{l}1.1 \\
3.3 \\
4\end{array}$ & $\begin{array}{l}0.2 \\
3.3 \\
1\end{array}$ & $\begin{array}{c}1.7 \\
10.0 \\
6\end{array}$ & $\begin{array}{c}2.1 \\
10.0 \\
6\end{array}$ & $\begin{array}{c}1.2 \\
10.0 \\
4\end{array}$ \\
\hline Urastoma cyprinae & $\begin{array}{l}a \\
b \\
c\end{array}$ & $\begin{array}{l}0.3 \\
3.3 \\
1\end{array}$ & $\begin{array}{c}2.9 \\
13.3 \\
5\end{array}$ & $\begin{array}{c}1.1 \\
10.0 \\
3\end{array}$ & $\begin{array}{l}0.2 \\
3.3 \\
1\end{array}$ & $\begin{array}{l}0.2 \\
3.3 \\
1\end{array}$ \\
\hline Proctoeces maculatus & $\begin{array}{l}a \\
b \\
c\end{array}$ & $\begin{array}{l}0.6 \\
3.3 \\
2\end{array}$ & $\begin{array}{l}0.6 \\
3.3 \\
3\end{array}$ & $\begin{array}{c}1.8 \\
10.0 \\
6\end{array}$ & $\begin{array}{l}0.2 \\
3.3 \\
1\end{array}$ & $\begin{array}{l}0.2 \\
3.3 \\
1\end{array}$ \\
\hline Mytilicola intestinalis & $\begin{array}{l}\mathrm{a} \\
\mathrm{b} \\
\mathrm{c}\end{array}$ & $\begin{array}{l}54.4 \\
73.3 \\
12\end{array}$ & $\begin{array}{l}33.6 \\
63.3 \\
14\end{array}$ & $\begin{array}{l}34.2 \\
66.7 \\
17\end{array}$ & $\begin{array}{l}4.8 \\
83.3 \\
17\end{array}$ & $\begin{array}{l}20.3 \\
46.7 \\
16\end{array}$ \\
\hline Disseminated neoplasia & $\begin{array}{l}\mathrm{a} \\
\mathrm{b} \\
\mathrm{c}\end{array}$ & $\begin{array}{l}0.6 \\
3.3 \\
2\end{array}$ & $\begin{array}{l}0.2 \\
3.3 \\
1\end{array}$ & $\begin{array}{l}0.2 \\
3.3 \\
1\end{array}$ & $\begin{array}{l}0 \\
0 \\
0\end{array}$ & $\begin{array}{l}0.2 \\
3.3 \\
1\end{array}$ \\
\hline Haemocytic infiltration & $\begin{array}{l}\mathrm{a} \\
\mathrm{b} \\
\mathrm{c}\end{array}$ & $\begin{array}{l}51.1 \\
96.7 \\
12\end{array}$ & $\begin{array}{l}36.4 \\
86.7 \\
15\end{array}$ & $\begin{array}{l}42.6 \\
96.7 \\
17\end{array}$ & $\begin{array}{l}30.3 \\
80.0 \\
16\end{array}$ & $\begin{array}{l}17.8 \\
56.7 \\
14\end{array}$ \\
\hline Granulocytomas & $\begin{array}{l}a \\
b \\
c\end{array}$ & $\begin{array}{l}13.9 \\
20.0 \\
12\end{array}$ & $\begin{array}{l}10.5 \\
26.7 \\
14\end{array}$ & $\begin{array}{l}21.2 \\
53.3 \\
17\end{array}$ & $\begin{array}{l}12.8 \\
53.3 \\
13\end{array}$ & $\begin{array}{l}7.3 \\
20.0 \\
13\end{array}$ \\
\hline Mean rank & & 2.4 & 3.2 & 2.3 & 3.5 & 3.6 \\
\hline
\end{tabular}




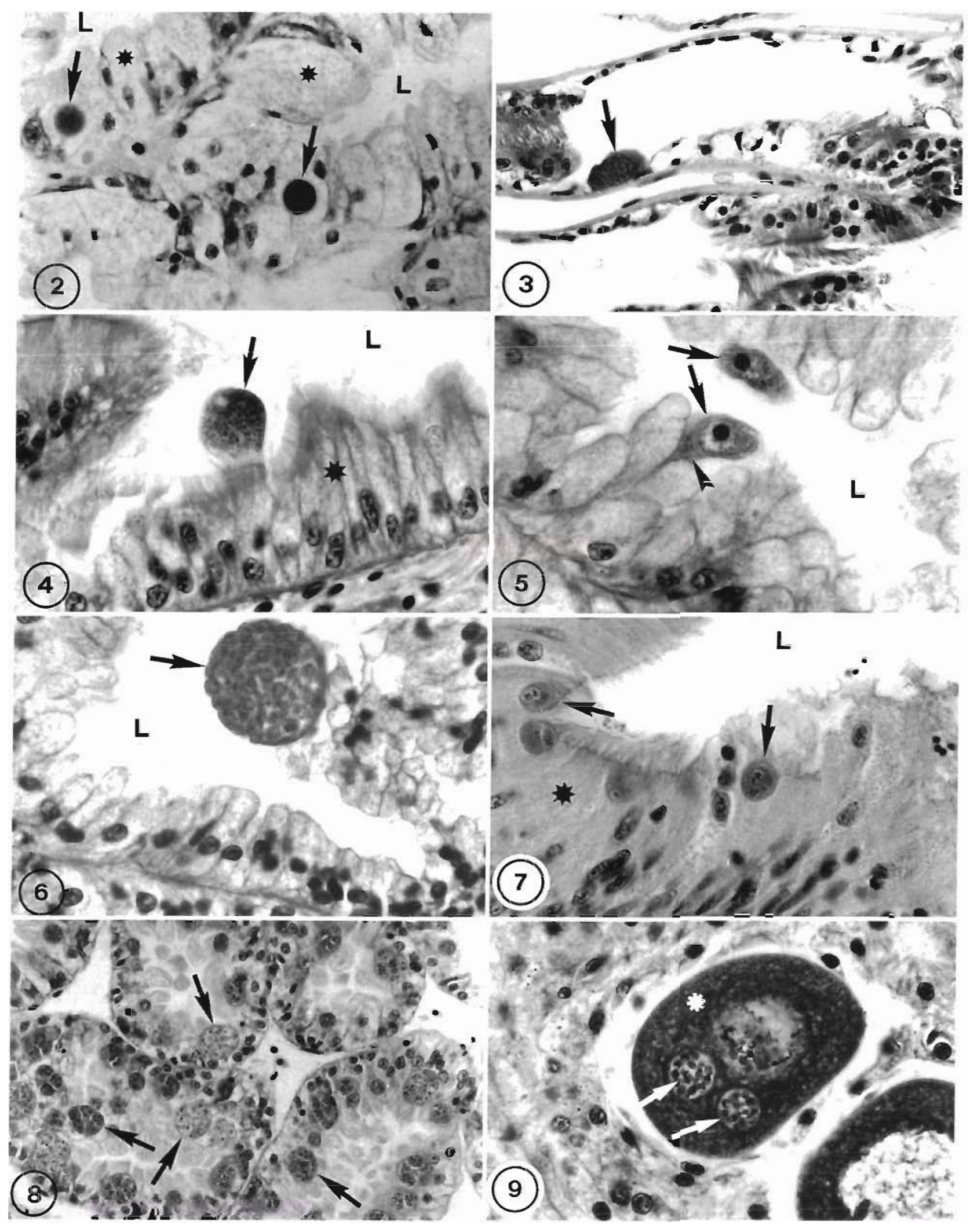


samples. Early stages consisted of spherical to elongated, multinucleate cells, up to $12 \mu \mathrm{m}$ long (Fig. 7). These vegetative stages were initially seen in the apical border of the stomach epithelium. The infection. spread through the epithelia of digestive diverticula, where sporulation occurred. The sporulation process produced 'pseudoplasmodia' up to $25 \mu \mathrm{m}$ long, enclosing 8 sporonts. Each sporont (ca $12 \mu \mathrm{m}$ in diameter) enclosed 4 spores. As spores developed, 3 to 7 highly refringent bodies within the sporonts became prominent (Fig. 8). Infection was associated with haemocytic infiltration of connective tissue and epithelia of the digestive gland. Extensive destruction of the digestive gland was observed in heavy infections. This parasite was found at all sites except Muros (Table 1). The earliest detection occurred after 4 mo of culture. Prevalence was somewhat higher in the second year of culture than in the first (see Fig. 18).

Cysts of the microsporidian Steinhausia mytilovum were detected in the cytoplasm of ovocytes of some female mussels. Cysts were spherical, 10 to $15 \mu \mathrm{m}$ in diameter, and contained numerous spores (1.5 to $2.5 \mu \mathrm{m}$ in diameter) with different degrees of maturity (Fig. 9). Up to 3 cysts per ovocyte were observed. Few infected ovocytes per section were found. A heavy haemocytic infiltration was very often observed inside affected gonadal follicles and in the connective tissue surrounding those follicles. This parasite was found at every site (Table 1). Prevalence (female mussels only) was higher in the second year of culture than in the first (see Fig. 18).

Two types of ciliates were found in the sampled mussels. Pear-shaped ciliates 7 to $15 \mu \mathrm{m}$ long were observed inside vacuoles of digestive tubule epithelia (Fig. 10). The nuclear apparatus was often fragmented into several micronuclei which were sometimes condensed into one macronucleus. More than one parasite was seldom seen in the same host cell. Infection intensity was mostly low. There was no haemocytic reaction and no lesions other than enlargement of ciliatebearing cells were observed. This intracellular ciliate was found at every site (Table 1). Its prevalence was higher in the second year of culture than in the first (see Fig. 18). Extracellular ciliates were observed either on the gill surface or in gill water tubes (Fig. 11). These ciliates did not elicit an inflammatory response and did not cause any obvious damage, although high numbers were seen in some sections. They were detected at every site (Table 1) and prevalence increased with time except for a decrease in winter (see Fig. 18)

Individuals of a Paravortex-like turbellarian were found only in intestinal lumina of some mussels. Most of these flatworms bore several embryonic capsules containing 2 embryos each, although non-gravid individuals were also seen (Fig. 12). Only one flatworm per section was found. Neither host injury nor host haemocytic reaction was observed. The earliest detection of this turbellarian occurred after 6 mo of culture at Vilagarcía. Its prevalence was low everywhere (Table 1) with no obvious temporal pattern (see Fig. 18).

Individuals of another turbellarian, Urastoma cyprinae, were detected wandering on gill filaments and in gill water tubes (Fig. 13). Macroscopically they were easily seen as tiny whitish spots on gill surface. A common effect was disorganization of gill architecture due to the movement of these flatworms through gill ostia and water tubes. Occasionally, a heavy haemocytic infiltration of gill tissues was observed near the worms; haemocytes passed through gill epithelia to surround the worms and some of the latter were seen partially destroyed. U. cyprinae was found in every site (Table 1). The few cases detected were mostly concentrated in the second year of culture (see Fig. 18).

Larval stages (sporocysts and cercariae) of the digenean trematode Proctoeces maculatus were found mostly in mantle, but also in digestive gland, foot, kidney and gills of some mussels (Fig. 14). Intensity varied from light, in which few sporocysts were observed, to heavy, in which normal tissues of the gonad and digestive gland were mostly replaced by densely packed sporocysts and cercariae. Heavy infections caused host castration and loss of storage tissue. A heavy inflammatory response was often elicited by this parasite

Figs. 2 to 9. Symbionts of Mytilus galloprovincialis. Fig. 2. Prokaryotic inclusion bodies (PIB) (arrows) in the epithelium ( $)$ of digestive tubules. L: lumen of digestive tubules. GTC staining, $\times 580$. Fig. 3. PIB (arrow) in a branchial filament. GTC staining, $\times 500$. Fig. 4. Unidentified protistan (arrow) attached to the epithelium ( ) of a digestive primary duct. L: lumen of digestive duct. GTC staining, $\times 825$. Fig. 5. Gamonts of a Pseudoklossia-like coccidian (arrows) in hypertrophied cells of kidney. Arrowhead indicates nucleus of hypertrophied kidney cell. L: nephridial lumen. GTC staining, $\times 825$. Fig. 6 . Mature oocyst of a $p_{s \in u d o-}$ klossia-like coccidian (arrow) enclosing numerous sporocysts in the kidney. L: nephridial lumen. H\&E staining, $\times 825$. Fig. 7. Early stages of Marteilia refringens (arrows) in the apical border of the stomach epithelium ( ). L: lumen of the stomach. H\&E staining, $\times 700$. Fig. 8. Different stages of the sporulation process of $M$. refringens (arrows) in the epithelium of digestive tubules. H\&E staining, $\times 325$. Fig. 9. Cysts of Steinhausia mytilovum (arrows) with mature spores in the cytoplasm of an ovocyte (*). The parasitized ovocyte is surrounded by host haemocytes. GTC staining, $\times 825$ 

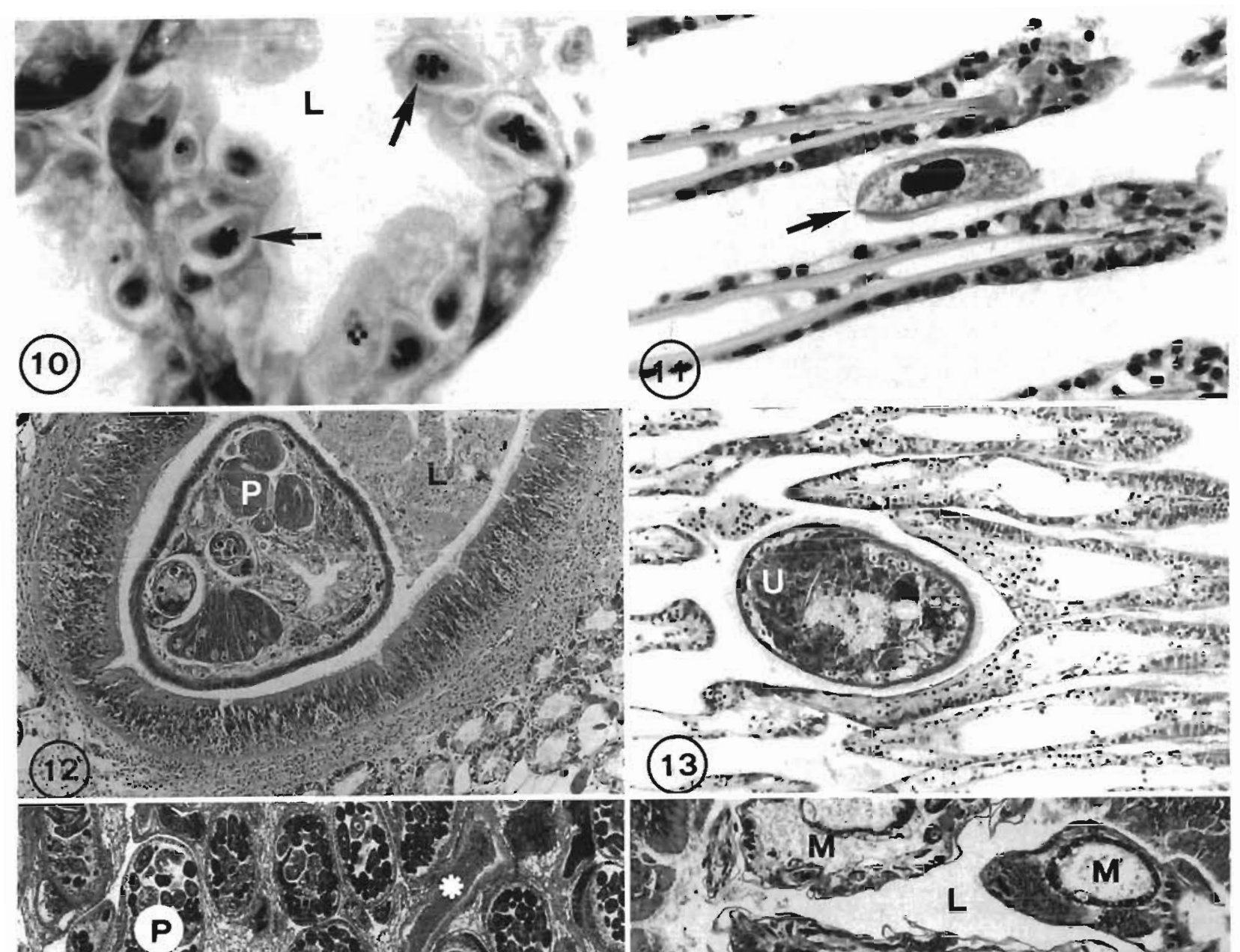

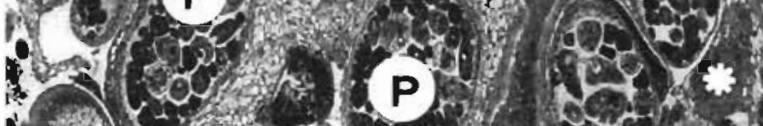
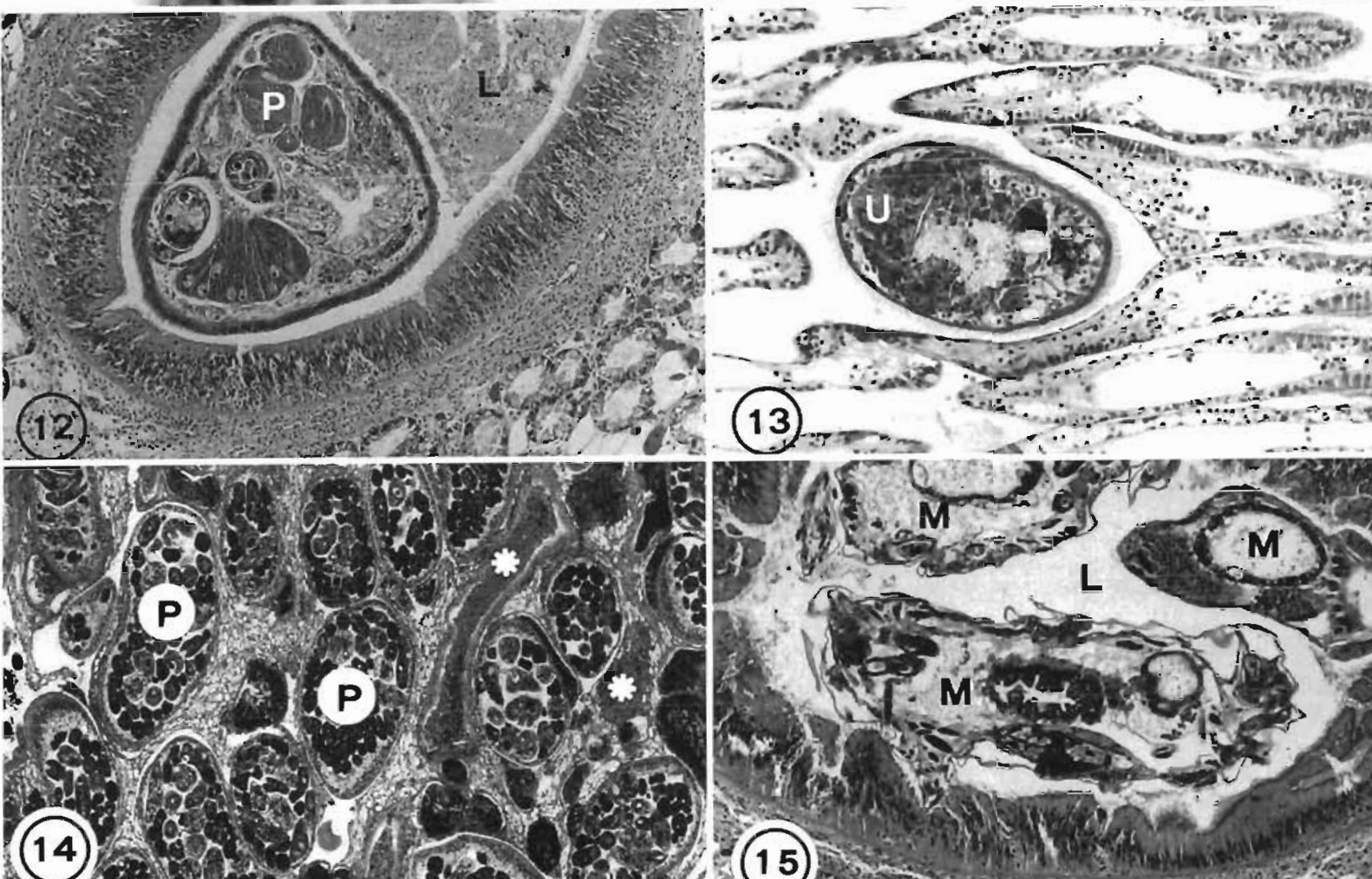
(u)
(13)

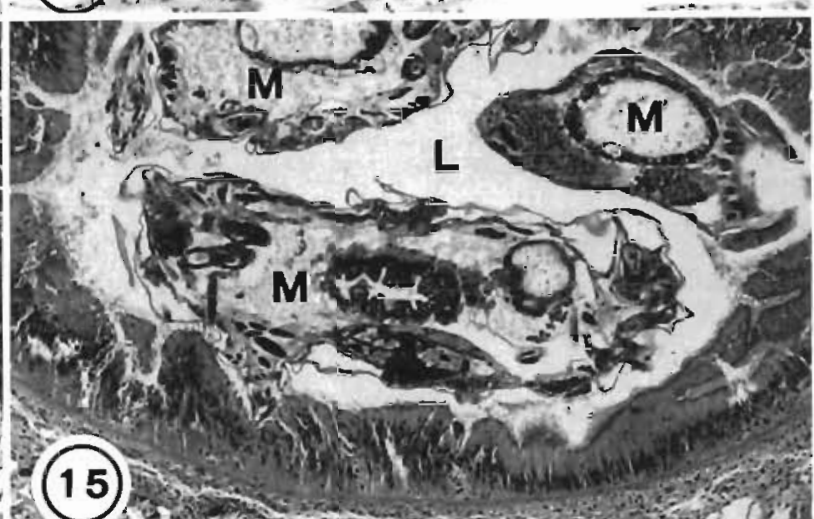

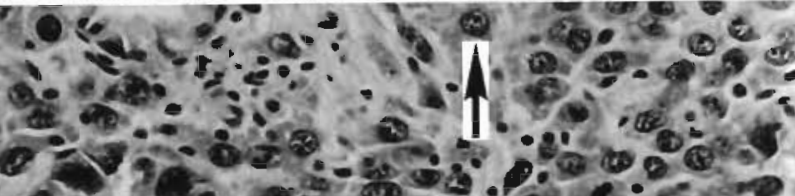

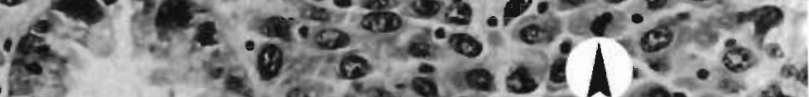

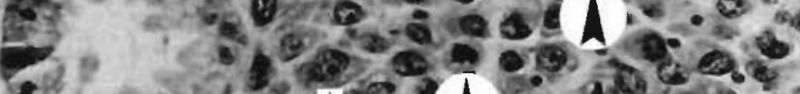

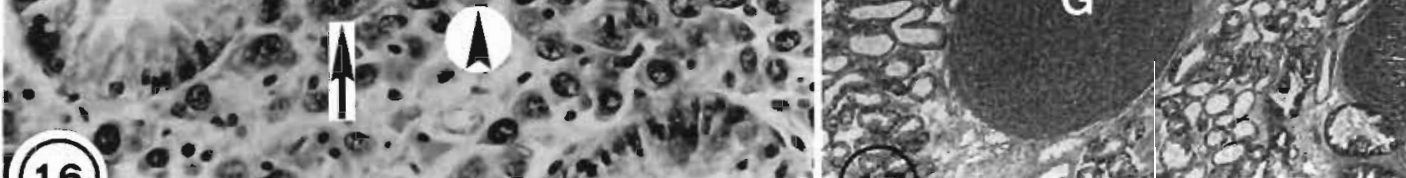

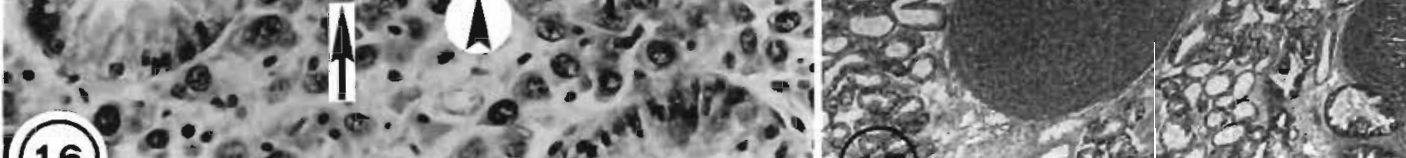
(16) $\%$ - a (1)

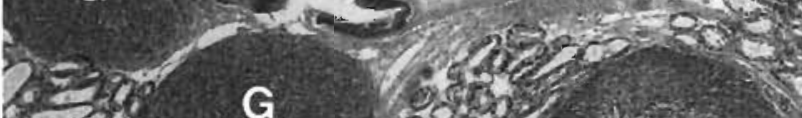
G

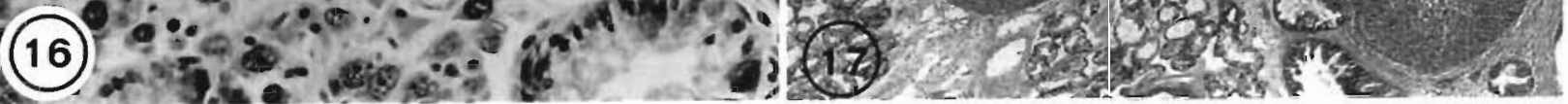


Figs. 10 to 17. Symbionts and pathological conditions of Mytilus galloprovincialis. Fig. 10. Pear-shaped ciliates (arrows) in the epithelial cells of digestive tubules. L: lumen of digestive tubules. H\&E staining, $\times 825$. Fig. 11. A ciliate (arrow) in the space between 2 consecutive branchial filaments. GTC staining, $\times 500$. Fig. 12. A. Paravortex-like turbellarian (P) in the intestinal lumen (L). H\&E staining, $\times 80$. Fig. 13. Urastoma cyprinae (U) in the gills. Gill filaments are distorted and slightly infiltrated by haemocytes in the vicinity of the flatworm. GTC staining, $\times 165$. Fig. 14. Sporocysts of Proctoeces maculatus (P) containing germ balls and cercariae in the mantle. Some gonad follicles () in the vicinity of sporocysts are heavily infiltrated by haemocytes due to host inflammatory reaction. H\&E staining, $\times 30$. Fig. 15 . Three copepods Mytilicola intestinalis (M) in the intestinal lumen (L). H\&E staining, $\times 80$. Fig. 16. Disseminated neoplasia. Cross section through the digestive gland of the mussel showing infiltration of connective tissue by neoplastic cells (arrows). Arrowheads indicate mitotic figures. H\&E staining, $\times 325$. Fig. 17. Cross section through the digestive gland showing large granulocytomas (G). H\&E staining, $\times 30$

including granulocytomas in which trematodes were encapsulated and frequently destroyed. Heavy infections were macroscopically evident; the mantle showed large masses of deep orange spots, concurrently with poor mussel condition. Prevalence of this parasite was very low at every site (Table 1); most were found in the second year of culture (see Fig. 18).

Individuals of the copepod Mytilicola intestinalis were seen in digestive lumina of many mussels. Adults were only located in the intestinal lumen of the host (Fig. 15), earlier stages of development were mostly found in the stomach and, rarely, on the gills. Up to 6 copepods were seen in a single section of the intestine. Occasionally, occurrence of the copepod was deduced from observation of egg-sacs in sections of the intestine. Copepod appendages caused erosion and metaplasia of intestinal epithelium. Haemocytic infiltration was often seen in intestinal epithelia and surrounding connective tissue near copepods. Infestation by this copepod was detected early at every site (Table 1), including the first sampling at Muros and Lorbé. Subsequently, its prevalence increased and reached higher values in the second year of culture (see Fig, 18).

Five mussels with a cellular proliferative disorder were found during the study. In 3, connective tissue of the organs was heavily infiltrated by hypertrophied cells, which were also observed in blood vessels. These transformed cells had a scant rim of cytoplasm and rounded-to-pleomorphic nuclei up to $15 \mu \mathrm{m}$ in length with finely dispersed chromatin and 1 or 2 prominent nucleoli. Mitotic figures were common in these cells (Fig. 16). Heavy infiltration by transformed cells caused hyperplasia of the plicate organ, dilation of gill filaments, atrophy of digestive diverticula, and destruction of gonadal follicles. In the other 2 affected mussels, transformed cells were observed only in blood vessels and sinuses around the stomach; no damage was observed. This lesion was diagnosed as disseminated neoplasia, occurring at all sites except Muros (Table 1). One histological section showing this condition was deposited in the Registry of Tumours in Lower Animals (Smithsonian Institution, Washington, DC) as accession number RTLA 5167.
Two histological signs of inflammatory reaction were observed through this study: haemocytic infiltration of tissues and occurrence of granulocytomas. Haemocytic infiltration mostly affected connective tissue but also epithelia of different organs. This reaction was frequently associated with the occurrence of parasites. Haemocytic infiltration was observed in mussels from every site (Table 1). So-called granulocytomas, focal concentrations of haemocytes (mostly granulocytes) inducing atrophy and autolysis of underlying tissue, were also detected (Figs. 17 \& 18). Granulocytomas were located mainly in the digestive gland, but also in the mantle, foot, and kidney. Extensive destruction of digestive diverticula was occasionally caused by these haemocytic concentrations. Sometimes parasites remnants showing different degrees of destruction (Marteilia refringens and Proctoeces maculatus among them) were seen within granulocytomas. This lesion was found everywhere (Table 1).

Fig. 19 shows the distribution of the sampled mussels of each site according to the number of different symbiont species and pathologic conditions detected in their tissues. The percentage of mussels with 3 or more different symbiont species and pathologic conditions was $35 \%$ in Moaña, $31 \%$ in Vilagarcía, $21 \%$ in Illa de Arousa, $15 \%$ in Muros, and $9 \%$ in Lorbé. Consistently, the highest average prevalence values of histological signs of stress (haemocytic infiltration and granulocytomas) corresponded to Moaña and Vilagarcía, intermediate values to Illa de Arousa and Muros, and the lowest value to Lorbé (Table 1). After ranking the sites in accordance with the average prevalence of each parasite and pathological condition, the lowest mean rank scores (due to higher average prevalence values) corresponded to Moaña and Vilagarcía, intermediate values to Illa de Arousa and Muros, and the highest value to Lorbé (Table 1). Mean rank differences were significant according to a Kruskal-Wallis test $(H=$ 10.95; $\mathrm{df}=4 ; \mathrm{p}=0.027$ ). However, posterior multiple comparison did not show significant differences among sites. 
DIGESTIVE GLAND PIB

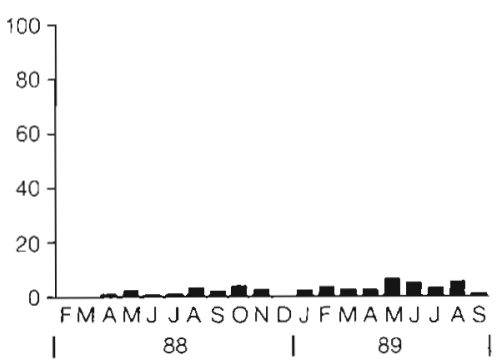

KIDNEY COCCIDIAN

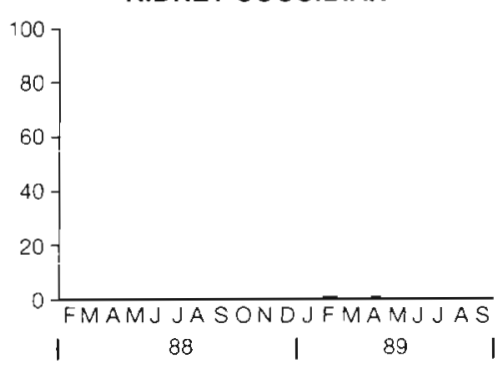

DIG. TUBULE CILIATES

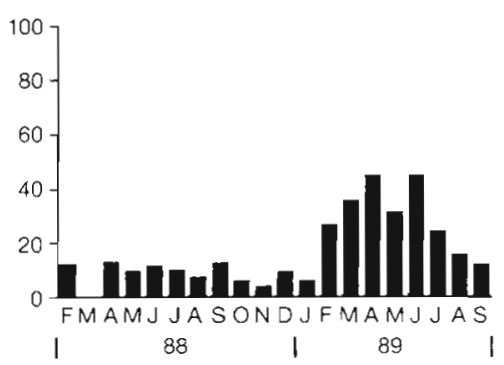

URASTOMA CYPRINAE

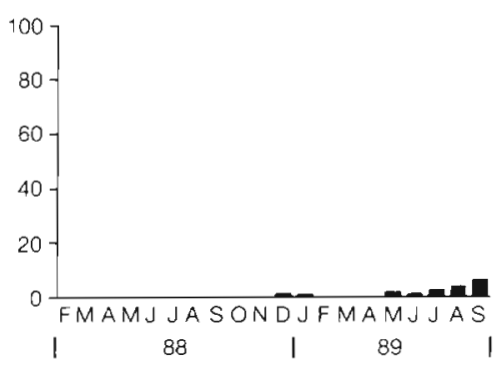

DISSEMINATED NEOPLASIA

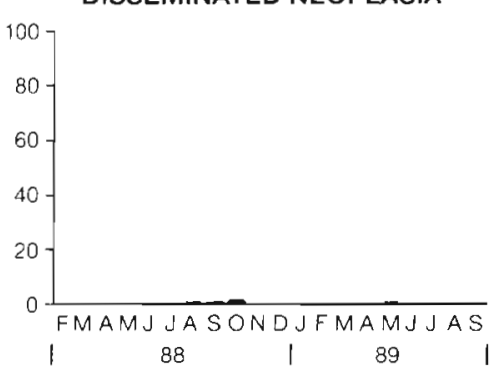

GILL PIB

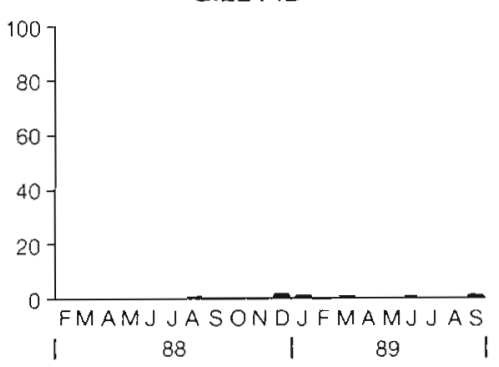

MARTEILIA REFRINGENS

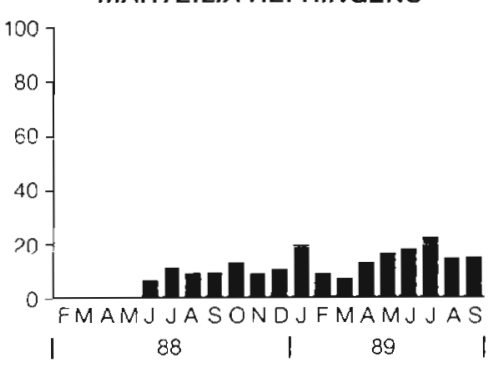

GILL CILIATES

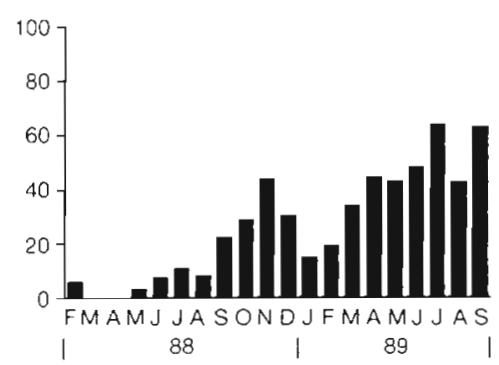

PROCTOECES MACULATUS

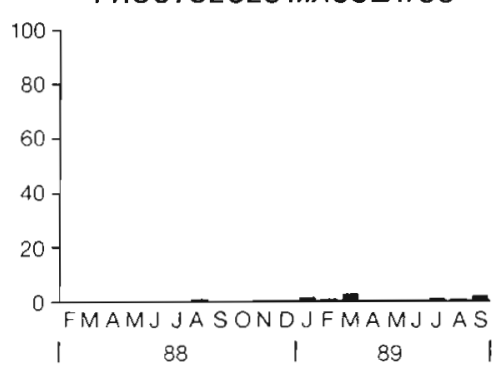

HEMOCYTIC INFILTRATION

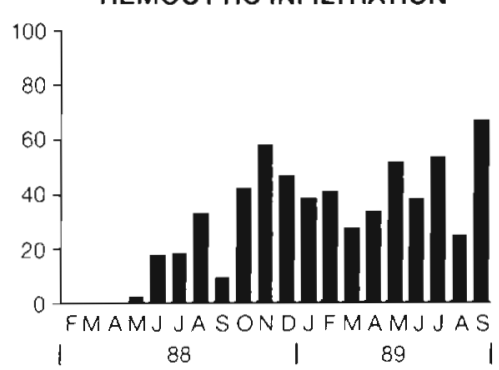

DIG. GL. UNIDENTIFIED PROTISTAN

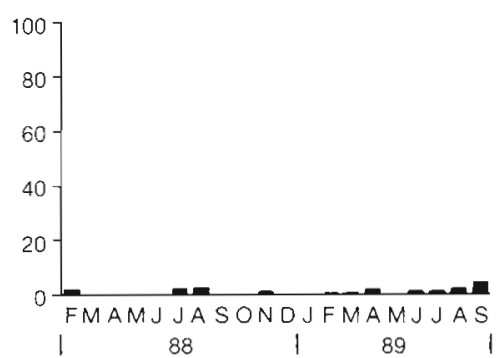

STEINHAUSIA MYTILOVUM

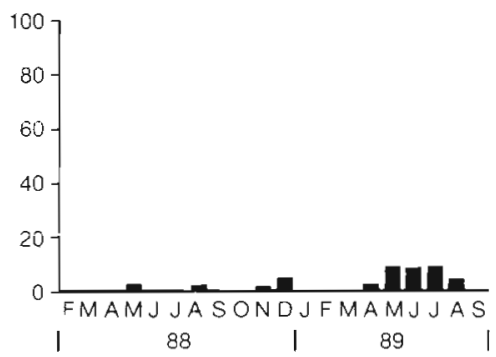

INTESTINE TURBELLARIAN
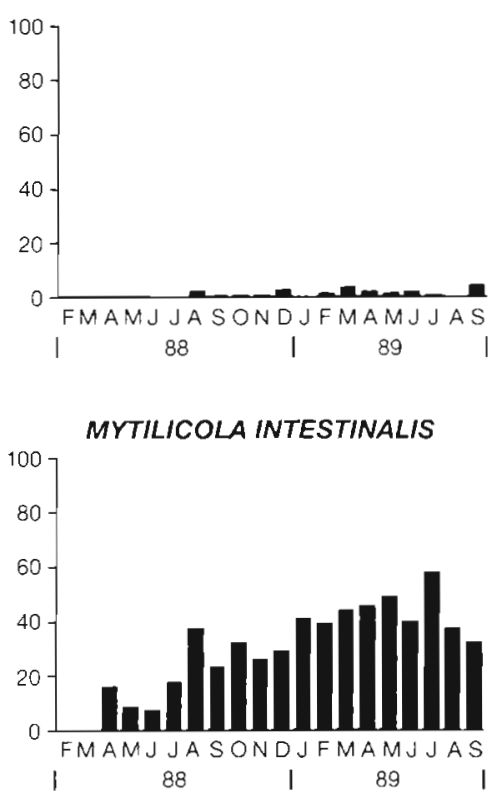

GRANULOCYTOMA

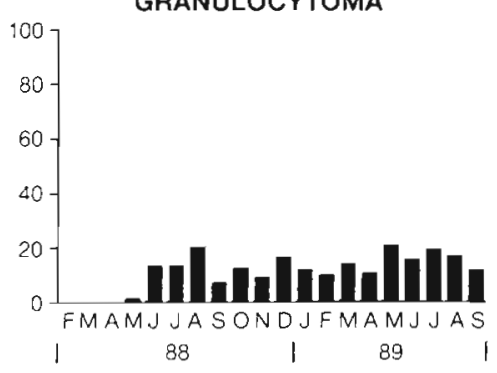

Fig. 18. Mytilus galloprovincialis. Monthly mean values of prevalence of each symbiont and pathological condition pooled for all sites 


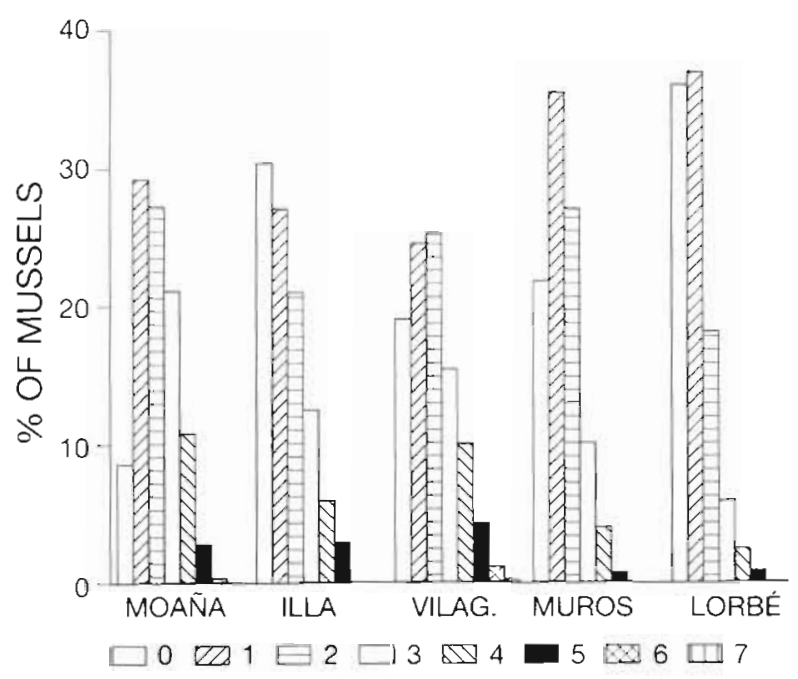

Fig. 19. Mytilus galloprovincialis. Distribution of the mussels sampled from each site during the whole study period in classes according to the number of different symbiont species and pathological conditions detected in each mussel. Classes are identified by different bar patterns

\section{DISCUSSION}

This study revealed the occurrence of various symbionts inhabiting mussels throughout the culture process in the Rías of Galicia. The symbionts were categorized into 3 groups according to their pathogenicity.

The first group consisted of symbionts with an unnoticeable (or very mild at most) pathogenic effect. They did not elicit any evident inflammatory response. This group includes PIB of digestive gland and gills, the unidentified protistan of digestive primary ducts, the kidney coccidian, the intracytoplasmic ciliates of digestive tubules, the gill ciliates, and the turbellarian of the intestinal lumen.

The PIB detected in digestive gland and gills strongly resembled Rickettsia/Chlamydia/Mycoplasmalike colonies reported from different bivalve species (Harshbarger et al. 1977, Le Gall et al. 1988, Fries \& Grant 1991). Nevertheless, without an ultrastructural study, their taxonomic position could not be established. The chlamydial character of similar spherical inclusion bodies found in the digestive gland of mussels from the Basque coast (N Spain) was disclosed by studying their fine structure (Cajaraville \& Angulo 1991). Robledo et al. (1994c) described similar inclusions of digestive tubules of cultured mussels from Ría de Vigo as Chlamydia-like organisms, based on the negative reaction with the Macchiavello method for Rickettsia. These authors also reported the occurrence of small inclusion bodies in the gills similar to the gill PIB described in our study. Rickettsia and chlamydia have been also found in other species of Mytilus from different regions, within cells of digestive diverticula, gills and kidney (Gulka \& Chang 1984, Figueras et al. 1991b, Bower 1992). There were no lesions in infected mussels. In contrast, rickettsial and chlamydial infections have been associated with mortalities in other bivalve species (Gulka et al. 1983, Elston 1986, Le Gall et al. 1988, Leibovitz 1989, Norton et al. 1993, Renault \& Cochennec 1995)

The unidentified protistan attached to primary digestive duct epithelium has not been described previously. Distinctive characters were not observed, but its morphology, location and position inside the host suggest an Apicomplexan parasite. A similar parasite was occasionally observed by one of us (A.V.) in oysters Crassostrea virginica collected in Chesapeake Bay (unpubl. data).

The gamonts and the oocyst of the coccidian observed in the kidney were similar to those of Pseudoklossia sp. and the Pseudoklossia-like coccidian reported from mussels of the East Coast of the USA and British Columbia, Canada (Farley 1988, Bower 1992). Figueras et al. (1991a) and Robledo et al. (1994c) also found oocysts of a Pseudoklossia-like coccidian in the kidney of cultured mussels from the Rías de Arousa and Vigo. Heavy infections by these coccidians may cause kidney damage but associated mortalities appear restricted to artificial growing conditions (Bower et al. 1994).

Intracytoplasmic ciliates of digestive tubules similar to those found in this study were also seen in cultured mussels from the Ría de Arousa by Figueras et al. (1991a), the Ría de Vigo (Robledo et al. 1994c) and mussels from other distant regions (Figueras et al. 1991b, Pekkarinen 1991, Bower 1992). These intracytoplasmic parasites were considered as Rhynchodidlike Phyllopharyngea ciliates by Bower et al. (1994). No lesions were reported.

Ciliates observed in the gills of the mussels throughout the study corresponded to different species, although most of them resembled Ancistrum mytili. They can be considered as commensals rather than parasites (Hatzidimitriou \& Berger 1977, Bower et al. 1994). A. mytili is ubiquitous in mussels (Mytilus spp.) throughout their geographical range (Bower et al. 1994). In Galicia, gill ciliates, sometimes identified as A. mytili, were reported from mussels cultured in the Rías Ares-Betanzos, Arousa and Vigo (González et al. 1987, Figueras et al. 1991a, Robledo et al. 1994c).

Although the average prevalence of the intestine turbellarian recorded through the study was low, its accurrence in mussels of Galicia cannot be considered accidental, since it was detected at every study site. This contrasts with the absence of other reports of turbellarians in the digestive lumen of any species of Mytilus, despite the wide geographical range of this 
genus. Turbellarians of the genus Paravortex are common inhabitants of the digestive tract of different bivalve species (Jennings 1971). The only species reported from mussels is Paravortex gemellipara, which was found in Geukensia demissa, Ischadium recurvum and Mytilopsis leucopheata (Wardle 1980). The study of Jennings \& Phillips (1978) on feeding and digestion of Paravortex spp. indicates a biochemical dependence of the flatworms on the host. Nevertheless, no pathogenic effect on the host has been described.

The second group consisted of symbionts that can cause perceptible damage to the host, although they are unlikely to be lethal. These symbionts frequently evoked inflammatory response. This group includes Steinhausia mytilovum, Urastoma cyprinae, and Mytilicola intestinalis.

Steinhausia mytilovum has a wide geographical range, including mussel ovocytes from the Atlantic and Pacific coasts of the USA and the Italian coast (Lauckner 1983, Hillman 1991). In Galicia, this parasite was reported from mussels cultured in the Rías de Arousa, Ares-Betanzos and Vigo (González et al. 1987, Figueras et al. 1991a, Robledo et al. 1994c). Parasitized ovocytes are likely infertile. Additionally, the heavy haemocytic reaction in the mantle gives rise to a reduction of the host storage tissue.

The occurrence of either Urastoma cyprinae or its macroscopic sign (whitish spots on the gills) in Galician mussels was not reported prior to 1988. Likely, this turbellarian was recently introduced into Galician waters. Today, its prevalence is close to $100 \%$ in adult mussels from every culture site in Galicia (unpubl. data). Robledo et al. (1994b) reported its occurrence in wild and cultured mussels from the Rías de Vigo, Pontevedra, and Arousa, studied morphological and histopathological aspects and concluded that this flatworm should be considered as a mussel parasite, since sometimes it causes gill lesions. Rodríguez et al. (1994) detected loss of condition in mussels bearing more than 10 worms, which was tentatively explained by branchial malfunction caused by the flatworms. However, $U$. cyprinae has been mostly reported as commensal with bivalves or free-living (Jennings 1971. Bower et al. 1994, Robledo et al. 1994b).

According to Bower et al. (1994), Mytilicola intestinalis is confined to Europe, from Denmark to Italy including the British Isles, but is not found in the Baltic Sea. Since this copepod has been reputed to be a mussel pest and is one of the most prevalent symbionts of Galician mussels, its biology and distribution in the rías were studied by different authors (Andréu 1963, 1965 , Figueras \& Figueras 1981, Paul 1983, Robledo et al. 1994c, Fuentes et al. 1995). The effects of this copepod on the host is controversial. It does not seem justified to blame the copepod for large-scale mortalities among mussels (Davey \& Gee 1988, Davey 1989), but it may cause loss of condition to the host (Theisen 1987). Limited histopathological changes in the mussel gut associated with the copepod were detected in our study.

The third group consisted of 2 parasites, Marteilia refringens and Proctoeces maculatus, able to cause severe, even fatal, damage to the host. Additionally, disseminated neoplasia could be included in this group due to its detrimental effect, although the aetiology of this lesion does not seem to be parasitic.

The results of this study regarding morphology, pattern of progression of the infection, temporal variability and distribution of the mussel parasite Marteilia refringens in Galicia were described elsewhere (Villalba et al. 1993b). Parasites infecting Mytilus galloprovincialis from the Mediteranean coast and Mytilus edulis from Brittany (France) similar to that of the Galician mussels were reported as Marteilia maurini (Comps et al. 1982, Auffret \& Poder 1985). Marteilia sp. was also reported from mussels cultivated in Apulia (S. Italy) (Tiscar et al. 1993). Monoclonal antibodies raised against Marteilia sp. purified from Brittany mussels $M$. edulis cross-reacted with $M$. refringens from Galician mussels M. galloprovincialis (Robledo et al. 1994a), but did not with Marteilia sydneyi from the oyster Saccostrea commercialis (Anderson et al. 1994). Heavy infections by $M$. refringens may cause a significant reduction of absorption efficiency, inhibition of gonad and storage tissue development, and loss of condition of the host (Villalba et al. 1993a, Villalba 1995). Association between mussel mortality and infection by this parasite was suggested (Villalba et al. 1993b, Fuentes et al. 1995). Its prevalence is influenced by environmental factors (culture site and depth) but not by the geographic origin of the mussel seed (Fuentes et al. 1995, Robledo \& Figueras 1995). Culture rafts are mostly located in the outer zones of the rias, where the prevalence of $M$. refringens is much lower, and that can contribute to minimizing the impact of this parasite on the mussel culture industry of Galicia.

Proctoeces maculatus has been reported under various synonyms as a mussel parasite from a wide geographic range, in both tropical and temperate marine waters (Lauckner 1983, Bower et al. 1994). In Galicia, larval stages of this trematode were found in cultured mussels from the Rías de Vigo, Arousa and AresBetanzos (Canzonier 1972, Ferrer 1981, González et al. 1987, Figueras et al. 1991a, Robledo et al. 1994c). The cases of heavy infection observed in our study were associated with extensive disruption of the invaded tissues and organs. Interference with the circulatory system, depletion of reserves, disturbance of gametogenesis leading up to complete castration, and death are among the effects that this parasite may have on 
the mussel (Lauckner 1983). However, the low prevalence values recorded in our study and in those cited above on the Galician rías suggest $P$. maculatus is not a threat to the mussel culture industry of Galicia.

Since the description of a 'sarcomatoid proliferative disease' in Oregon (USA) mussels (Farley 1969), cases of disseminated neoplasia have been reported from Mytilus spp. of Great Britain, the Baltic Sea (Denmark and Finland), the Atlantic and Pacific coasts of the USA, and British Columbia (Peters 1988, Elston et al. 1992). Within the genus Mytilus, disseminated neoplasia reaches epizootic levels (and causes significant mortality) only in $M$. trossulus populations but is seldom observed in $M$. edulis and $M$. galloprovincialis (Elston et al. 1992). In Galicia, Gutiérrez \& Sarasquete (1986) and Figueras et al. (1991a) found one single mussel with this neoplastic condition in each of their respective surveys. This condition frequently progresses to a fatal outcome, but some individuals can recover (Elston et al. 1992). Nevertheless, disseminated neoplasia should not be considered as a threat to the mussel culture industry of Galicia since its prevalence is very low in the region.

Average prevalence higher than $10 \%$ was recorded at every study site only for Mytilicola intestinalis, gill ciliates, and digestive gland ciliates, which could be considered the component species of the symbiont community associated with farmed mussels in Galicia. Average prevalence of Marteilia refringens was also higher than $10 \%$ in 3 study sites. The remaining symbionts could be considered as rare.

Qualitative composition of the mussel symbiont community was similar at the 5 study sites. However, the gill PIB, the kidney coccidian and Marteilia refringens were not detected at some of the study sites. This was also the case for the disseminated sarcoma. Quantitatively, symbiont loads were higher and histological signs of stress more abundant in Moana and Vilagarcía (the most inner sites in the Rías), lower in Lorbé, and intermediate in Illa de Arousa and Muros. The inner zones of the Galician Rías have lower rates of water renewal and higher levels of pollution than the outer zones. Therefore, encounters between mussels and infective stages of parasites are more probable and stress levels higher in the inner zones. This could help to explain quantitative differences among the study sites.

Prevalence of most of the symbionts increased as mussels grew, probably because of the increased filtration rate associated with mussel growth. The unidentified protistan of the digestive gland, gill and digestive gland ciliates, and Mytilicola intestinalis were detected in mussel seed at the beginning of the experimental cultures. Therefore, transplantation of mussel seed for culture could contribute to the spread of some symbionts throughout the Rías.
Acknowledgements. The following mussel farmers generously helped to carry out the experimental cultures: Mr José Rouco Camiña in Moaña, Mr Armando Otero in llla de Arousa, Mr José Padín in Vilagarcía, Mr Pedro Caamaño in Muros, and $\mathrm{Mr}$ Alberto López Saavedra and Mr Jaime Montes in Lorbé. Ms Maribel Meléndez, Ms Elena Penas, and Ms Teresa Andrade provided technical assistance. This research was supported by funds of the Consellería de Pesca, Marisqueo e Acuicultura da Xunta de Galicia. S.G.M. was supported by a FPI scholarship from the Ministerio de Educación y Ciencia of Spain.

\section{LITERATURE CITED}

Anderson TJ, McCaul TF, Boulo V, Robledo JAF, Lester RJG (1994) Light and electron immunohistochemical assays on paramyxean parasites. Aquat Living Resour 7:47-52

Andréu B (1963) Propagación del copépodo parásito Mytilicola intestinalis en el mejillón cultivado en las rías gallegas (NW de España). Invest Pesq 24:3-20

Andréu B (1965) Biología y parasitología del mejillón gallego. Las Ciencias 30:107-118

Auffret M, Poder M (1985) Recherches sur Marteilia maurini, parasite de Mytilus edulis sur les côtes de Bretagne Nord. Rev Trav Inst Pêches Marit 47:105-109

Bayne BL, Brown DA, Burns K, Dixon DR, Ivanovici A, Livingstone DR, Lowe DM, Moore MN, Stebbing ARD, Widdows $\mathbf{J}$ (1985) The effects of stress and pollution on marine animals. Praeger, New York

Bower SM (1992) Diseases and parasites of mussels. In: Gosling E (ed) Developments in aquaculture and fisheries science, Vol 25. The mussel Mytilus: ecology, physiology, genetics and culture. Elsevier, Amsterdam, p 543-563

Bower SM, McGladdery SE, Price IM (1994) Synopsis of infectious diseases and parasites of commercially exploited shellfish. Annu Rev Fish Dis 4:1-199

Cajaraville MP, Angulo E (1991) Chlamydia-like organisms in digestive and duct cells of mussels from Basque coast. J Invertebr Pathol 58:381-386

Canzonier WJ (1972) Cercaria tenuans. Larval trematode parasite of Mytilus edulis and its significance in mussel culture. Aquaculture 1:267-278

Comps M, Pichot Y, Papagianni P (1982) Recherche sur Marteilia maurini n. sp. parasite de la moule Mytilus galJoprovincialis Lmk. Rev Trav Inst Pêches Marit 45: $211-214$

Davey JT (1989) Mytilicola intestinalis /Copepoda, Cyclopoida): a ten year survey of infested mussels in a Cornish estuary, 1978-1988. J Mar Biol Assoc UK 69:823-836

Davey JT, Gee JM (1988) Mytilicola intestinalis, a copepod parasite of blue mussel. Am Fish Soc, Spec Publ 18:64-73

Elston RA (1986) An intranuclear pathogen [nuclear inclusion $X$ (NIX)] associated with massive mortalities of the Pacific razor clam Siliqua patula. J Invertebr Pathol 47:93-104

Elston RA, Moore DJ, Brooks K (1992) Disseminated neoplasia of bivalve molluscs. Rev Aquat Sci 6:405-466

FAO (1992) Aquaculture production 1984-1990. FAO Fish Circ 815 (Rev 4)

Farley CA (1969) Sarcomatoid proliferative disease in a wild population of blue mussels (Mytilus edulis). J Natn Cancer Inst 43:509-516

Farley CA (1988) A computerized coding system for organs, tissues, lesions, and parasites of bivalve mollusks and its application in pollution monitoring with Mytilus edulis. Mar Environ Res 24:243-249 
Ferrer JR (1981) Estructura y ultraestructura del esporocisto de un tremátodo parásito del mejillón Mytilus edulis L. Bol R Soc Esp His Nat Secc Biol 79:5-14

Figueras A, Figueras AJ (1981) Mytilicola intestinalis Steuer en el mejillón de la Ría de Vigo (NO. de España). Invest Pesq 45:263-278

Figueras AJ, Jardón CF, Caldas JR (1991a) Diseases and parasites of rafted mussels (Mytilus galloprovincialis Lmk) preliminary results. Aquaculture 99:17-33

Figueras AJ, Jardón CF, Caldas JR (1991b) Diseases and parasites of mussel (Mytilus edulis, Linnaeus, 1758) from two sites on the east coast of the United States. J Shellfish Res 10:89-94

Fries CR, Grant DM (1991) Rickettsiae in gill epithelial cells of the hard clam. Mercenaria mercenaria. J Invertebr Pathol 57:166-171

Fuentes JM, Villalba A, Zapata C, Álvarez G (1995) Effects of stock and culture environment on infections by Marteilia refringens and Mytiliculd intestinalis in the mussel Mytilus galloprovincialis cultured in Galicia (NW Spain). Dis Aquat Org 21:221-226

González P, Quintana R. Pascual C (1987) Estudio parasitológico del mejillón de batea. Cuad Marisq Publ Téc 12 $671-676$

Gulka G, Chang PW (1984) Host response to rickettsial infection in blue mussel, Mytilus edulis L. J Fish Dis 8 : $319-323$

Gulka G, Chang PW, Marti KA (1983) Prokaryotic infection associated with a mass mortality of the sea scallop, Placopecten magellanicus. J Fish Dis 6:355-364

Gutiérrez M (1977) Nota sobre marteiliasis en el mejillón, Mytilus edulis L., de la costa Noroeste de España. Invest Pesq 41:637-642

Gutiérrez M (1978) Cercaria tenuans y Marteilia refringens en un ejemplar de mejillón Mytilus edulis de la costa Noroeste de España. Invest Pesq 42:467-470

Gutiérrez M, Sarasquete MC (1986) Un caso de hemocitosarcoma hialino en el mejillón, Mytilus edulis L. (Pelecypoda: Mytilidae) de la costa NO. de España. Invest Pesq 50: $265-269$

Harshbarger JC, Chang SC, Otto SV (1977) Chlamydiae (with phages), mycoplasmas and rickettsiae in Chesapeake Bay bivalves. Science 196:666-668

Hatzidimitriou G, Berger J (1977) Morphology and morphogenesis of Ancistrum mytili (Scuticociliatida: Thigmotrichina) a commensal ciliate of mytilid pelecypods. Protistologica 13:477-495

Hillman RE (1991) Steinhausia mytilovum (Minisporida: Chitridiopsidae) in Mytilus sp. in California: a new geographic record. J Invertebr Pathol 57:144-145

Howard AW, Smith CS (1983) Histological techniques for marine bivalve mollusks. NOAA Technical Memorandum NMFS-F/NEC-25, Woods Hole

Jennings JB (1971) Parasitism and commensalism in the Turbellaria. Adv Parasitol 9:1-32

Jennings JB, Philips JI (1978) Feeding and digestion in three endosymbiotic graffillid rhabdocoels from bivalve and gastropod molluscs. Biol Bull (Woods Hole) 155:542-562

Lauckner G (1983) Diseases of Mollusca: Bivalvia. In: Kinne O (ed) Diseases of marine animals, Vol II, Bivalvia to Scaphopoda. Biologische Anstalt Helgoland, Hamburg, p $477-961$

Le Gall G, Chagot D, Mialhe E, Grizel H (1988) Branchial Rickettsiales-like infection associated with a mass mortality of sea scallop Pecten maximus. Dis Aquat Org 4: $229-232$

Leibovitz L (1989) Chlamydiosis: a newly reported serious disease of larval and postmetamorphic bay scallops, Argopecten irradians (Lamarck). J Fish Dis 12:125-136

Luna LG (ed) (1968) Manual of histologic staining methods of the Armed Forces Institute of Pathology, 3rd edn. McGraw-Hill, New York

Norton JH, Shepherd MA, Abdor-Naguil MR, Lindsay S (1993) Mortalities in the giant clam Hippopus hippopus associated with Rickettsiales-like organisms. J Invertebr Pathol 62:207-209

Paul JD (1983) The incidence and effects of Mytilicola intestinalis in Mytilus edulis from the Rías of Galicia, North West Spain. Aquaculture 31:1-10

Pekkarinen M (1991) Notes on the general condition of Mytilus edulis $\mathrm{L}$. off the southwestern coast of Finland. Bivalve Studies in Finland 1:20-40

Pérez-Camacho A, González R, Fuentes J (1991) Mussel culture in Galicia (NW Spain). Aquaculture 94:263-278

Peters EC (1988) Recent investigations on the disseminated sarcomas of marine bivalve molluscs. Am Fish Soc, Spec Publ 18:74-92

Renault T, Cochennec N (1995) Chlamydia-like organisms in ctenidia and mantie cells of the Japanese oyster Crassostrea gigas from the French Atlantic coast. Dis Aquat Org 23:153-159

Robledo JAF, Figueras A (1995) The effects of culture-site, depth, season, and stock source on the prevalence of Marteilia refringens in cultured mussels (Mytilus galloprovincialis Lmk.) from Galicia, Spain. J Parasitol 81: $354-363$

Robledo JAF, Boulo V, Mialhe E, Desprès B, Figueras A (1994a) Monoclonal antibodies against sporangia and spores of Marteilia sp. (Protozoa: Ascetospora). Dis Aquat Org 18:211-216

Robledo JAF, Cáceres-Martínez J, Sluys R, Figueras A (1994b) The parasitic turbellarian Urastoma cyprinae (Plathyhelminthes: Urastomidael from blue mussel Mytilus galloprovincialis in Spain: occurrence and pathology. Dis Aquat Org 1.8:203-210

Robledo JAF, Santarém MM, Figueras A (1994c) Parasite loads of rafted blue mussels (Mytilus galloprovincialis) in Spain with special reference to the copepod Mytilicola intestinalis. Aquaculture 127:287-302

Rodríguez S, Quintana R, Collazo JL, Pascual C (1994) Effet du turbellarié Urastoma sur l'indice de condition des moules cultivées dans 'La Ría de Arosa' NO Espagnol. European Aquaculture Society, Spec Publ 21:257-258

Sokal RR, Rohlf FJ (1981) Biometry, 2nd edn. WH Freeman and Co, New York

Tenore KR, Boyer LF, Cal RM, Corral J, Garcia-Fernández C, González N, González-Gurriarán E, Hanson RB, Iglesias $\mathrm{J}$, Krom M, López-Jamar E, McClain J, Pamatmat MM Pérez A, Rhoads DC, De Santiago G, Tietjen J, Westrich J, Windon HL (1982) Coastal upwelling in the Rias Bajas, NW Spain: contrasting the benthic regimes of the Rias de Arosa and de Muros. J Mar Res 40:701-772

Theisen BF (1987) Mytilicola intestinalis Steuer and the condition of the host Mytilus edulis L. Ophelia 27:77-86

Tiscar PG. Tempesta M. Compagnucci M (1993) Peroxidase conjugated polyclonal antibody against Marteilia sp. purified from infected mussels (Mytilus galloprovincialis, Lmk) cultivated in Apulia, southern Italy. Bull Eur Assoc Fish Pathol 13.53-55

Villalba A (1995) Estudio de la marteiliasis del mejillón. Efectos de esta enfermedad en el mejillón cultivado en las rías gallegas. Xunta de Galicia, Santiago de Compostela

Villalba A, Mourelle SG, Carballal MJ, López MC (1993a) Effects of infection by the protistan parasite Marteilia 
refringens on the reproduction of cultured mussels Mytilus galloprovincialis in Galicia (NW Spain). Dis Aquat Org 17:205-213

Villalba A, Mourelle SG, López MC, Carballal MJ, Azevedo C (1993b) Marteiliasis affecting cultured mussels Mytilus galloprovincialis of Galicia (NW Spain). I. Etiology, phases

Editorial responsibility: Albert Sparks,

Seattle, Washington, USA of the infection, and temporal and spatial variability in prevalence. Dis Aquat Org 16:61-72

Wardle WJ (1980) Occurrence of the symbiotic rhabdocoele flatworm Paravortex gemellipara in Chesapeake Bay and Gulf of Mexico molluscs, with notes on its biology and geographical range. Estuaries 3:84-88

Submitted: November 6, 1996; Accepted: August 8, 1997

Proofs received from author(s): October 10, 1997 